\title{
Pemahaman Siswa Kelas VIII SMP Pada Materi Relasi dan Fungsi Tahun Pelajaran 2019/2020
}

\author{
A'ayatul Maulana ${ }^{1 *}$, Sripatmi $^{2}$, Junaidi ${ }^{3}$, Nani Kurniati ${ }^{4}$ \\ ${ }^{1}$ Mahasiswa Pendidikan Matematika, Universitas Mataram, Mataram, Indonesia \\ ${ }^{2}$ Pendidikan Matematika, Universitas Mataram, Mataram, Indonesia
}

*Corresponding Author e-mail: ayatulmaulana1997@gmail.com

Received: 27-01-2021; Revised: 08-02-2021; Published: 25-03-2021

\begin{abstract}
The purpose of this study was to determine the category of understanding of class VIII students of a school in Labuapi on the subject matter of relations and functions of the 2019/2020 school year in terms of four types of Polya's understanding. This type of research is quantitative research with descriptive methods. The population in this study was all eighth grade students of a school in Labuapi 2019/2020 school year. The samples in this study were 30 people in class VIII D. Sampling was done by cluster random sampling technique. Data collection instruments in this study used tests. The test is given to measure the students' understanding of the relation and function material which consists of seven questions and is done in 60 minutes. Based on the results of data analysis in the study showed that the category of understanding of class VIII students of SMPN 2 Labuapi on the subject matter of relations and functions in terms of four types of understanding of Polya, namely mechanical, inductive, rational and intuitive understanding, was very low and for the relationship between each type of understanding on average had a strong relationship.
\end{abstract}

Keywords: Understanding, Relationships and Functions

\begin{abstract}
Abstrak
Tujuan penelitian ini adalah untuk mengetahui kategori pemahaman siswa kelas VIII sebuah sekolah di Labuapi pada materi relasi dan fungsi tahun pelajaran 2019/2020 ditinjau dari empat jenis pemahaman Polya. Jenis penelitian yang digunakan adalah penelitian kuantitatif dengan metode deskriptif. Populasi dalam penelitian ini adalah seluruh siswa kelas VIII di sebuah sekolah di Labuapi tahun pelajaran 2019/2020. Sampel dalam penelitian ini sebanyak 30 orang pada kelas VIII D. Pengambilan sampel dilakukan dengan teknik cluster random sampling. Instrumen pengumpulan data dalam penelitian ini menggunakan tes. Tes diberikan untuk mengukur pemahaman yang dimiliki siswa terhadap materi relasi dan fungsi yang terdiri dari tujuh soal dan dikerjakan dalam waktu 60 menit. Berdasarkan hasil analisis data pada penelitian menunjukkan bahwa kategori pemahaman siswa kelas VIII pada materi relasi dan fungsi ditinjau dari empat jenis pemahaman Polya yaitu pemahaman mekanikal, induktif, rasional dan intuitif berkategori sangat rendah dan untuk hubungan antara tiap jenis pemahaman rata-rata memiliki hubungan kuat.
\end{abstract}

Kata Kunci: Pemahaman, Relasi dan Fungsi

Cara Mengutip

Maulana, A., Sripatmi, Junaidi \& Kurniati, N. (2020). Pemahaman Siswa Kelas VIII SMP Pada Materi Relasi dan Fungsi Tahun Pelajaran 2019/2020. GRIYA Journal of Mathematics Education and Application, 1(1), 29-35. 


\section{PENDAHULUAN}

Matematika merupakan mata pelajaran yang diajarkan di berbagai jenis jenjang pendidikan, dimulai dari jenjang pendidikan dasar hingga jenjang perguruan tinggi. Hal tersebut merupakan salah satu bukti yang menunjukan bahwa matematika merupakan mata pelajaran yang sangat penting dalam dunia pendidikan. Pembelajaran matematika sendiri memiliki beberapa tujuan. Tujuan dari pembelajaran matematika adalah agar siswa memiliki kemampuan sebagai berikut; i) Meningkatkan kemampuan intelektual, khususnya kemampuan tingkat tinggi siswa; ii) Membentuk kemampuan siswa dalam menyelesaikan sebuah masalah secara sistematik; iii) Memperoleh hasil pembelajaran yang tinggi; iv) Melatih siswa dalam mengkomunikasikan ide-ide, khususnya dalam karya ilmiah; dan v) Mengembangkan karakter (Depdiknas, 2013).

Salah satu faktor yang menentukan keberhasilan dalam pembelajaran matematika saat ini adalah pemahaman siswa terhadap materi yang diajarkan. Pemahaman matematika merupakan landasan penting untuk berpikir dalam menyelesaikan permasalahan matematika maupun permasalahan sehari-hari. Pemahaman materi merupakan bagian yang sangat penting, dengan memberikan pengertian bahwa materi-materi yang diajarkan kepada siswa bukan hanya sebagai hafalan, namun lebih dari itu, sehingga dengan adanya pemahaman siswa dapat lebih mengerti akan materi pelajaran yang disampaikan.

Berdasarkan hasil ulangan harian siswa kelas VIII SMPN 2 Labuapi pada materi Relasi dan Fungsi dapat dilihat pada Tabel 1 dibawah ini.

Tabel 1. Nilai rata-rata Ulangan Harian Materi Relasi dan Fungsi Siswa Kelas VIII SMPN 2 Labuapi Tahun pelajaran 2019/2020

\begin{tabular}{llll}
\hline No & Kelas & Rata-Rata Nilai & Ketuntasan Klasikal \\
\hline 1 & VIII-A & 40,89 & $6,428 \%$ \\
2 & VIII-B & 50 & $10 \%$ \\
3 & VIII-C & 60,275 & $10,965 \%$ \\
4 & VIII-D & 50 & $10 \%$ \\
\hline & & (sumber: daftar nilai guru matematika kelas VIII SMPN 2 Labuapi)
\end{tabular}

Berdasarkan tabel di atas ketuntasan klasikal siswa di bawah 50 \%. Ini berarti masih banyak siswa yang mendapatkan nilai dibawah KKM yaitu 70. Dapat disimpulkan bahwa pemahaman siswa masih kurang, dan mengakibatkan nilai tidak memenuhi KKM. Berdasarkan data tersebut peneliti tertarik untuk melakukan penelitian tentang pemahaman siswa terhadap materi relasi dan fungsi untuk mengetahui bagaimana kategori pemahaman siswa kelas VIII SMPN 2 Labuapi.

Pemahaman berasal dari kata kata "paham" yang artinya mengerti benar tentang sesuatu hal (Porwadaminta, 1991). Pemahaman adalah tingkat kemampuan yang mengharapkan siswa mampu memahami arti atau materi, situasi serta fakta yang diketahuinya (Purwanto, 1994). Secara umum ada empat macam pengertian pemahaman, yakni sebagai berikut; i) Pemahaman berarti melihat hubungan yang belum nyata; ii) Pemahaman berarti mampu menerangkan atau dapat melukiskan tentang 
aspek-aspek, tingkatan, sudut pandangan-pandangan yang berbeda; iii) Pemahaman berarti memperkembangkan kesadaran akan faktor-faktor yang penting; dan iv) Berkemampuan membuat ramalan yang beralasan mengenai tingkah lakunya (Partowisastro, 1983).

Pemahaman dapat dibagikan kedalam tiga kategori, yakni sebagai berikut; i) Tingkat pertama atau terendah yaitu pemahaman terjemahan yang mulai dari terjemahan dalam arti sebenarnya; ii) Tingkat kedua adalah pemahaman penafsiran, yakni menghubungkan bagian- bagian terdahulu dengan yang diketahui berikutnya, atau menghubungkan beberapa bagian dari grafik dengan kejadian, membedakan yang pokok dan yang bukan pokok; iii) Pemahaman tingkat ketiga atau tingkat tertinggi, yakni pemahaman ekstrapolasi. Dengan ekstrapolasi diharapakan mampu melihat dibalik yang tertulis, dapat membuat ramalan tentang konsekuensi atau dapat memperluas persepsi dalam arti waktu, dimensi, kasus, ataupun masalahnya (Sudjana, 2010).

Secara garis besar pemahaman dibedakan menjadi empat jenis pemahaman; i) Pemahaman mekanikal, yaitu dapat mengingat dan menerapkan sesuatu secara rutin atau perhitungan sederhana; ii) Pemahaman induktif, yaitu dapat mencobakan sesuatu dalam kasus sederhana dan tahu bahwa sesuatu itu berlaku dalam beberapa kasus serupa; iii) Pemahaman rasional, yaitu dapat membuktikan kebenaran sesuatu; iv) Pemahaman intuitif, yaitu dapat memperkirakan kebenaran sesuatu tanpa ragu-ragu, sebelum menganalisis secara analitik (Polya, 1973).

Sedangkan pengetahuan dan pemahaman siswa terhadap materi matematika dapat dilihat dari kemampuan siswa dalam; i) Mendefinisikan materi secara verbal dan tulisan; ii) Mengidentifikasi dan membuat contoh dan bukan contoh; iii) Menggunakan model, diagram dan simbol-simbol untuk mereprensentasikan suatu materi; iv) Mengubah suatu bentuk representasi ke bentuk lainnya; v) Mengenal berbagai makna dan interpretasi materi; vi) Mengidentifikasi sifat-sifat suatu materi dan mengenal syarat yang menentukan suatu materi; vii) Membandingkan dan membedakan materi-materi (NCTM, 1989).

\section{METODE}

Jenis penelitian ini adalah penelitian kuantitatif dengan metode deskriptif. Populasi yang diambil dalam penelitian ini adalah seluruh siswa kelas VIII SMPN 2 Labuapi yang terdiri dari 4 kelas yaitu kelas A, B, C dan D tahun pelajaran 2019/2020. Teknik pengambilan sampel yang digunakan dalam penelitian ini adalah cluster random sampling. Sebelum melakukan pengambilan sampel secara cluster random sampling terlebih dahulu dilakukan uji homogenitas, tujuannya untuk mengetahui apakah semua populasi tersebut homogen atau tidak. Uji homogenitas yang digunakan adalah uji-F. Dari hasil uji homogenitas diperoleh nilai $f_{\text {hitung }}<\mathrm{f}_{\text {tabel. }}$ Kemudian setelah dilakukan uji homogenitas selanjutnya dilakukan pengambilan sampel secara acak. Teknik ini digunakan karena sampel penelitian ini menggunakan satu kelas yaitu kelas VIII-D dari seluruh kelas VIII SMPN 2 Labuapi tahun pelajaran 2019/2020. Teknik pengumpulan data pada penelitian ini dengan cara memberikan tes yang terdiri dari tujuh soal. Tes 
diberikan untuk mengukur pemahaman yang dimiliki siswa terhadap materi relasi dan fungsi yang dikerjakan dalam waktu 60 menit.

Sebelum digunakan untuk mengumpulkan data, instrumen terlebih dahulu di uji validitasnya. Uji validitas yang digunakan pada penelitian ini yaitu validitas isi (content validity). Dalam hal ini penentuan validitas instrumen akan didasarkan pada pendapat dua orang ahli matematika. Berdasarkan uji validitas yang telah dilakukan didapatkan hasil bahwa instrumen dinyatakan layak digunakan (valid). Uji reliabilitas instrumen dilakukan dengan menggunakan rumus Alpha Cronbach (Arikunto, 2010). Berdasarkan uji reliabilitas yang dilakukan dengan menggunakan Alpha Cronbach, didapatkan hasil bahwa intrumen dinyatakan reliabel dengan nilai $r_{11}=0,87$, hal ini berarti instrumen yang telah diuji memiliki reliabilitas sangat tinggi, Pada penelitian ini, untuk teknik analisis data yang digunakan adalah analisis deskriptif. Setelah memperoleh skor siswa, maka dilakukan analisis pemahaman menggunakan $M_{i}$ (Mean Ideal) dan $S D_{i}$ (Standar Deviasi Ideal) dengan rumus sebagai berikut (Nurkencana, Wayan Sunarta, 1990).

$$
\begin{gathered}
M_{i}=\frac{1}{2} \times(\text { skor tertinggi }+ \text { skor terendah }) \\
S D_{i}=\frac{1}{3} \times M_{i}
\end{gathered}
$$

Berdasarkan rumus di atas maka nilai $M i$ dan $S D i$ dalam analisis data adalah sebagai berikut.

$$
\begin{gathered}
M_{i}=\frac{1}{2} \times(25+0)=12,5 \\
S D_{i}=\frac{1}{3} \times 12,5=\frac{12,5}{3}=4,16
\end{gathered}
$$

Setelah diperoleh nilai $M_{i}$ dan $S D_{i}$, maka akan dilakukan penentuan kriteria tingkat pemahaman siswa dalam menyelesaikan soal matematika. Pedoman kriteria tingkat pemahaman tersebut dapat dilihat pada tabel berikut.

Tabel 2. Kategori Tingkat Pemahaman Siswa Dalam Menyelesaikan Soal Matematika Untuk Masing-Masing Jenis Pemahaman

\begin{tabular}{lcc}
\hline \multicolumn{1}{c}{ Interval skor } & Interval skor & $\begin{array}{c}\text { Kategori } \\
\text { Pemahaman }\end{array}$ \\
\hline \multicolumn{1}{c}{$X \geq M i+1,5 S D i$} & $x \geq 18,74$ & Sangat tinggi \\
$M i+0,5 S D i \leq X<M i+1,5$ & $14,58 \leq x<18,74$ & Tinggi \\
$S D i$ & $10,42 \leq x<14,58$ & Sedang \\
$M i-0,5 S D i \leq X<M i+0,5$ & $6,26 \leq x<10,42$ & Rendah \\
$S D i$ & $x<6,26$ & Sangat rendah \\
$M i-1,5 S D i \leq X<M i-0,5$ & $X<M i-1,5 S D i$ &
\end{tabular}

Keterangan : $X=$ Nilai rata-rata kemampuan siswa

Untuk mencari jumlah persentase banyaknya siswa pada masing-masing kategori tingkat pemahaman digunakan rumus sebagi berikut:

$$
p_{j}=\frac{n_{j}}{N} \times 100 \%
$$


Keterangan:

$p_{j}=$ Persentase banyaknya siswa pada kategori tingkat pemahaman $j$.

$j$ = Sangat tinggi, tinggi, sedang, rendah dan sangat rendah.

$n_{j}=$ Banyaknya siswa pada kategori tingkat pemahaman $j$.

$N=$ Jumlah semua siswa (Priyanto \& dkk., 2015).

Berdasarkan rumus di atas, dapat dikelompokkan tingkat pemahaman dengan kategori sangat tinggi, tinggi, sedang, rendah, dan sangat rendah. Untuk mengetahui hubungan dari jenis-jenis pemahaman yang dilakukan dapat digunakan analisis data uji pearson product moment atau analisis korelasi. Analisis korelasi adalah mencari hubungan variabel bebas (x) dengan variabel terikat (y) dan data berbentuk interval dan ratio (Riduwan, 2014). Harga $r$ akan dikonsultasikan dengan interprestasikan nilai $r$ sebagai berikut.

Tabel 3. Interpretasi koefisien korelasi nilai $r$

\begin{tabular}{cc}
\hline Interval Kooefisien & Tingkat Hubungan \\
\hline $0,00-0,19$ & Sangat Rendah \\
$0,20-0,39$ & Rendah \\
$0,40-0,59$ & Cukup \\
$0,60-0,79$ & Kuat \\
$0,80-1,00$ & Sangat Kuat \\
\hline
\end{tabular}

\section{HASIL DAN PEMBAHASAN}

Berdasarkan dari hasil penelitian masih terdapat siswa yang kurang paham dalam menyelesaikan soal matematika. Untuk mengetahui persentase banyaknya siswa pada masing-masing kategori dan masing-masing jenis pemahaman dapat dilihat pada Tabel 4 sebagai berikut.

Tabel 4. Persentase Banyaknya Siswa Pada Setiap Kategori Pemahaman Polya

\begin{tabular}{lllllllll}
\hline Kategori & \multicolumn{2}{l}{$\begin{array}{l}\text { Pemahaman } \\
\text { Mekanikal }\end{array}$} & \multicolumn{2}{l}{$\begin{array}{l}\text { Pemahaman } \\
\text { Induktif }\end{array}$} & \multicolumn{2}{l}{$\begin{array}{l}\text { Pemahaman } \\
\text { Rasional }\end{array}$} & \multicolumn{3}{l}{$\begin{array}{l}\text { Pemahaman } \\
\text { Intuitif }\end{array}$} \\
\cline { 2 - 9 } & $\begin{array}{l}\text { Banyak } \\
\text { (siswa) }\end{array}$ & persen & $\begin{array}{l}\text { Banyak } \\
\text { (siswa) }\end{array}$ & Persen & $\begin{array}{l}\text { Banyak } \\
\text { (siswa) }\end{array}$ & Persen & $\begin{array}{l}\text { Banyak } \\
\text { (siswa) }\end{array}$ & persen \\
\hline $\begin{array}{l}\text { Sangat } \\
\text { Tinggi }\end{array}$ & 10 & $33,33 \%$ & 3 & $10 \%$ & 9 & $30 \%$ & 3 & $10 \%$ \\
Tinggi & 1 & $3,33 \%$ & 0 & $0 \%$ & 0 & $0 \%$ & 0 & $0 \%$ \\
Sedang & 3 & $10 \%$ & 0 & $0 \%$ & 6 & $16,67 \%$ & 1 & $3,33 \%$ \\
$\begin{array}{l}\text { Rendah } \\
\text { Sangat }\end{array}$ & 9 & $30 \%$ & 12 & $40 \%$ & 1 & $3,33 \%$ & 0 & $0 \%$ \\
Rendah & 7 & $23,33 \%$ & 15 & $50 \%$ & 15 & $50 \%$ & 26 & $86,67 \%$ \\
\hline
\end{tabular}

Berdasarkan hasil penelitian, secara umum pemahaman siswa kelas VIII SMPN 2 Labuapi pada materi relasi dan fungsi lebih mendominasi pada pemahaman mekanikal dimana nilai rata-ratanya sebesar 12,43 dengan kategori sedang. Hal ini menunjukkan bahwa siswa kelas VIII SMPN 2 Labuapi sudah cukup mampu untuk mengingat, 
mendefinisikan, menggunakan model, diagram dan simbol-simbol untuk merepresentasikan suatu materi. Sedangkan untuk pemahaman intuitif siswa dikategorikan sangat rendah dengan nilai rata-rata 4,1. Hal ini menunjukkan bahwa siswa kelas VIII SMPN 2 Labuapi masih sangat kurang mampu dalam mengenal berbagai makna, memperkirakan kebenaran sesuatu tanpa ragu-ragu sebelum menganalisis secara analitik.

Bentuk-bentuk pemahaman siswa pada tiap jenis pemahaman merupakan bukti kurangnya kemampuan pemahaman siswa dalam menyelesaikan soal matematika pada materi relasi dan fungsi. Setiap jenis pemahaman yang dilalui siswa mulai dari pemahaman mekanikal, pemahaman induktif, pemahaman rasional dan pemahaman induktif masih banyak siswa yang kurang memahami materi, sehingga menyebabkan rendahnya pemahaman pada siswa. Hal ini sesuai dengan pernyataan (Yusniati et al., 2018) yang menyatakan bahwa pemahaman siswa masih tergolong rendah pada materi relasi dan fungsi.

Selanjutnya untuk hubungan tiap-tiap pemahaman sebagai berikut.

Tabel 5. Hubungan Jenis-Jenis Pemahaman

\begin{tabular}{llll}
\hline $\begin{array}{l}\text { Korelas } \\
\mathrm{i}\end{array}$ & \multicolumn{1}{c}{$r$} & $\begin{array}{l}\text { Tingkat } \\
\text { Hubungan }\end{array}$ & Keterangan \\
\hline $\mathrm{X} 1, \mathrm{X} 2$ & 0,7 & Kuat & Ada hubungan yang kuat antara X1 dengan X2 \\
& 2 & & \\
$\mathrm{X} 1, \mathrm{X} 3$ & 0,7 & Kuat & Ada hubungan yang kuat antara X1 dengan X3 \\
& 2 & & \\
$\mathrm{X} 1, \mathrm{X} 4$ & 0,6 & Kuat & Ada hubungan yang kuat antara X1 dengan X4 \\
& 1 & & \\
$\mathrm{X} 2, \mathrm{X} 3$ & 0,7 & Kuat & Ada hubungan yang kuat antara X2 dengan X3 \\
& 9 & & \\
$\mathrm{X} 2, \mathrm{X} 4$ & 0,8 & Sangat Kuat & Ada hubungan yang sangat kuat antara X2 dengan X4 \\
& 6 & & \\
$\mathrm{X} 3, \mathrm{X} 4$ & 0,6 & Kuat & Ada hubungan yang kuat antara X3 dengan X4 \\
& 7 & & \\
\hline
\end{tabular}

Keterangan:

$\mathrm{X} 1$ = Pemahaman Mekanikal, X2 = Pemahaman Induktif,

X3 = Pemahaman Rasional, X4 = Pemahaman Intuitif

Berdasarkan hasil uji korelasi dengan menggunakan uji korelasi Pearson Product Moment, didapatkan hubungan antara jenis pemahaman yang satu dengan jenis pemahaman yang lainnya. Untuk nilai koefisien korelasi jenis pemahaman mekanikal dengan pemahaman induktif, jenis pemahaman mekanikal dengan pemahaman rasional, jenis pemahaman mekanikal dengan pemahaman intuitif, jenis pemahaman induktif dengan pemahaman rasional, dan jenis pemahaman rasional dengan pemahaman intuitif masing masing sebesar 0,72, 0,72, 0,61, 0,79 dan 0,67 dengan tingkat hubungan kuat. Selanjutnya untuk nilai koefisien korelasi jenis pemahaman induktif dengan intuitif adalah sebesar 0,86 menunjukkan bahwa hubungan antara jenis pemahaman induktif dengan intuitif sangat kuat. Hal ini membuktikan bahwa hubungan antara jenis pemahaman yang satu dengan jenis pemahaman yang lain saling mempengaruhi antara satu dengan yang lain. 


\section{PENUTUP}

Berdasarkan hasil penelitian dan pembahasan yang telah dipaparkan maka dapat diambil kesimpulan bahwa pemahaman siswa kelas VIII SMPN 2 Labuapi terhadap materi relasi dan fungsi dengan cara menyelesaikan soal berdasarkan jenis pemahaman Polya adalah pemahaman mekanikal dengan kategori sedang dengan rata-rata 12,43 , pemahaman induktif dan rasional dengan kategori rendah dengan rata-rata berturutberturut 6,4 dan 9,67, pemahaman intuitif dengan kategori sangat rendah dengan ratarata 4,1 . Hubungan antara jenis pemahaman yang satu dengan jenis pemahaman yang lainnya adalah bertingkat hubungan kuat pada nilai koefisien korelasi jenis pemahaman mekanikal dengan pemahaman induktif, jenis pemahaman mekanikal dengan pemahaman rasional, jenis pemahaman mekanikal dengan pemahaman intuitif, jenis pemahaman induktif dengan pemahaman rasional, dan jenis pemahaman rasional dengan pemahaman intuitif masing masing sebesar 0,72, 0,72, 0,61, 0,79 dan 0,67. Selanjutnya untuk nilai koefisien korelasi jenis pemahaman induktif dengan intuitif adalah sebesar 0,86 dengan tingkat hubungan sangat kuat. menggambarkan jawaban atas hipotesis dan atau tujuan penelitian atau temuan ilmiah yang diperoleh. Kesimpulan tidak mengandung pengulangan hasil dan diskusi, melainkan merangkum temuan seperti yang diharapkan dalam tujuan atau hipotesis.

\section{REFERENSI}

Arikunto, S. (2010). Prosedur Penelitian Suatu Pendekatan Praktik. PT Rineka Cipta.

Depdiknas. (2013). Lampiran Peraturan Menteri Pendidikan Nasional Republik Indonesia Nomor 22 Tahun 2013 Tentang Standar Isi. BSNP.

NCTM. (1989). Curiculum and Evaluation Standarsds for school Mathematics. NCTM.

Nurkencana, Wayan Sunarta, S. (1990). Evaluasi Hasil Belajar. Usaha Nasional.

Partowisastro, K. (1983). Dinamika dalam Psikologi Pendidikan (1st ed.). Erlangga.

Polya, G. (1973). How to Solve It. Princeton University Press.

Porwadaminta. (1991). Kamus Besar Bahasa Indonesia. Balai Pustaka.

Priyanto, A., \& dkk. (2015). Analisis Kesalahan Siswa dalam Menyelesaikan Soal Cerita Matematika Pokok Bahasan Teorema Pythagoras Berdasarkan Kategori Kesalahan Newman di Kelas VIII A SMP Negeri 10 Jember. Artikel Ilmiah Mahasiswa Unirversitas Jember, 1(1), 1-5.

Purwanto. (1994). Prinsip-Prinsip dan Teknik Evaluasi Pengajaran Pendidikan. Remaja Rosda Karya.

Riduwan. (2014). Dasar-Dasar Statistika. Alfabeta.

Sudjana, N. (2010). Penilaian Hasil Proses Belajar Mengajar. Remaja Rosda Karya.

Yusniati, Y., Halini, H., \& Sayu, S. (2018). Deskripsi Pemahaman Konsep Siswa Pada Materi Fungsi di Kelas XI SMK Negeri 1 Sadaniang. Jurnal Pendidikan Dan Pembelajaran Khatulistiwa, 7(7), 1-8. 